\title{
Extrusion Technology of Soybeans and Obtained Product Feeding Effect on Lactating Sows and Their Offsprings Productivity.
}

\author{
Imants Jansons \\ Department of Plant Breeding and \\ Agroecology \\ Institute of Agricultural Resources \\ and Economics \\ Latvia \\ imants.jansons@arei.lv
}

\author{
Lilija Degola \\ Institute of Animal Sciences \\ Latvia University of Life Sciences \\ and Technologies, \\ Latvia \\ lilija.degola@llu.lv
}

\author{
Vita Sterna \\ Department of Plant Breeding and \\ Agroecology \\ Institute of Agricultural Resources \\ and Economics \\ Latvia \\ vita.sterna@arei.lv
}

\begin{abstract}
The aim of study was to estimate the processing technology of soybeans produced in Latvia and to compare the possibilities of using the obtained soybean cake with imported soybean meal in the feeding of lactating sows and their offspring. From soybeans, which were processed into animal feed, we obtained a product with a high content of protein. The control group of sows and fattening pigs received the imported soybean meal mixed into the compound feed, but the trial groups compound feed was mixed with soybean cake grown and processed in Latvia. Fattening pigs were weighed regularly. Feed consumption was counted and feed conversion was calculated. Was determined meat quality, carcases weight, carcases length. The chemical composition of the manure was analysed. Statistical analysis of data was performed with SAS / STAT 9.22 software package. The inclusion of soy cakes grown and processed in Latvia in lactating sow feed increased sow milk yields traits by $3.9 \%$ at 21 day of piglet age. At the end of experiment higher live weight by $3.42 \%$ were found in the trial group. Carcass quality indicators and chemical composition of meat did not show significant differences. Was observed a tendency to decrease in manure the content of organic matter in the trial group by $3.25 \%$, decrease levels of total phosphorus and ammonium nitrogen compared to the control group. Using soybean cakes grown and processed in Latvia is possible to develop feed rations that showed similar pig growth results to imported soybean meal.
\end{abstract}

Keywords - extrusion technology, soybean cakes, pig feeding.

\section{INTRODUCTION}

Soybean cultivation in Latvia is a new industry with many challenges. On 2019 in Latvia were declared 320 ha with soybean sowings. In Latvia soybeans is used for oil production, food and livestock feeding. Soybean meal is one of the most important protein sources in animal nutrition and is widely used in pig feeding. It has high biological value and digestibility, and considerable energy content. Unfortunately, in recent years, soybean meal has become so expensive [1], [2], [3], [4]. In Latvia, opportunities are being sought to grow soybeans and process them into feed to provide pigs with high-quality protein and reduce feed costs.

Even though they are a great source of amino acids the impairment of legumes' nutritional value is attributed in part to the presence of different compounds classically known as toxic and/or antinutritional factors, which act as direct or indirect antagonists of nutrient availability [4], [5]. For soybean seeds, trypsin inhibitor and lectin are considered to be the major proteins responsible for poor nutritional value [6], they cannot be consumed raw. The reason for that is because they also consist of antinutritional factors such as trypsin inhibitors, urease and lectins that adversely affect digestive efficiency. To reduce the anti-nutritional factors to minimum levels acceptable to your livestock, poultry, pet food or aqua species, the soybean needs to be processed [7].

Trypsin inhibitors are sensitive to denaturation by heat treatment. The vast majority of soybean products used for livestock feeds are heat-treated in order to eliminate any anti-nutritional effects associated with feeding raw soybeans [8].

Extrusion may be used to increase the nutritional value of feed ingredients or diets fed to pigs [9], [10]. The use of 
a combination of heat, pressure, and moisture that is applied to the feed during extrusion may gelatinize starch and improve apparent ileal digestibility of starch in feed ingredients [11] although duration of the extrusion procedure may influence the degree of gelatinization. Extrusion of cereal grains also increased concentrations of metabolizable energy in corn, and sorghum and extrusion may increase the apparent total tract digestibility of gross energy in high fiber diets [10] indicating that the increase in energy digestibility may be caused not only by increased starch digestibility but also by solubilization of fiber[11].

There are many factors that go into extruding soybeans properly such as using the correct temperature, equipment, resources, etc. With proper extrusion of soybeans, there are multiple additional benefits aside from already reducing anti-nutritional factors such as: reducing bitter flavors, denatures protein, frees the oil by rupturing plant cell walls, deactivating fat enzymes to promote stability/ shelf life [7].

Extrusion is a unique processing operation that uses high temperature and pressure over a short time, in which high shear forces are applied to produce a feed product with distinct physical and chemical characteristics. Extrusion as the most efficient energy intensive feed process gives better cooking effect of the starch and proteins than any other commercial processes. [12].

The aim of study was to estimate the processing technology of soybeans produced in Latvia and to compare the possibilities of using the obtained soybean cake with imported soybean meal in the feeding of lactating sows and their offspring.

\section{MATERIALS AND METHODS}

The study was conducted on a commercial farm at year 2020. In the extrusion process were include complete all soybean processing steps - separation of soybean husks, separation of oil from full-fat soya, extrusion the core of soybean and, cooling of soybean cakes. Soybeans were processed in the working body of the extruder 25 to 40 seconds the pressure generated heat in the extruder barrel was $130-140^{\circ} \mathrm{C}$. Production volume was $500 \mathrm{~kg}$ per hour.

The estimations of lactating sows were based on the ethical guidelines. Research was carried out in accordance with the Pig welfare requirements Regulations of the Cabinet of Ministers No. 743 [13]. Were completed 2 groups control group and trial group 18 sows in each. In both groups were included pregnant sows inseminated with the following: 8 sows Yorkshire $x$ Landrace (M1), 2 Yorkshire and 4 Landrace inseminated with a Pietren boar and 4 Landrace sows inseminated with a Yorkshire boar.

In the control groups diet was included imported soybean meal mixed with compound feed, and the experimental group included soybean cakes grown and extruded by the local farm. The other feed additives and feed nutrients were the same. In the experiment were calculated and prepared diets for each group similar in crude protein content and to be isoenergetic for metabolizable energy. The rations contained barley, wheat, canola or soybean oil, soybean meal or soybean cakes, salt and trace element vitamin premix, phytase. The compound feeds were fed to the sows in a dry, flowing manner.

The chemical composition of feed was determined with follows methods; protein content was determined (LVS NE ISO 5983-2:2009).Fat content was ISO 6492:1999. Amino acids detected using amino acids analyzer. The identity and quantitative analysis of the amino acids were assessed by comparison with the retention times and peak areas of the standard amino acid mixture. Ash were determined using ISO 5984: 2002/Cor1: 2005, calcium determined using LVS EN ISO 6869:2002, phosphorus using ISO 6491:1998, crude fibre determined using ISO 5498: 1981, methods [14].

During the study, the live weight of the piglets was regularly monitored by weighing on days 1, 21 and when they were weaned from the sows on the day 28 , the dead piglets were counted.

In order to evaluate the impact of imported soybean meal and local soybean cake on the growth and quality indicators of fattening pigs, two groups were completed with 40 animals in each. Piglets were taken from sows in a previous experiment. Pigs were regularly weighed at 28, 66,115 , and at the end of the experiment at 168 days of age, when they reached the realization end weight. Feed consumption was counted and feed conversion was calculated.

Carcasses weight was determined and carcasses length from the anterior tip of the aitch bone to the anterior edge of the first rib and next to the vertebra was measured [15]. The lean meat content in the carcases was detected by the ZP two-point method [16]. For quality testing 24 hours after slaughter meat samples were taken from the musculus longissimus lumborum et thoracis. Amino acids in meat samples were determined by ISO 13903: 2005, total protein LVS ISO 937: 1978, total fat content LVS ISO 1443: 1973IC-UV, cholesterol, BIOR-T-012-132-2011, moisture LVS ISO 1442: 1997, pH LVS ISO 2917: 2004, tryptophan (total) EU 152/2009, LC-FLD methods[17].

Manure samples were taken from each group included in the study. The chemical composition of manure was determined by standard methods in the laboratory of SIA "Vides audits"; dry matter LVS EN 13040: 2008, total nitrogen LVS EN 13654-1: 2003 / NAC: 2004, total potassium LVS ISO 11466: 1995, LVS ISO 9964-3: 2000, total phosphorus LVS 398: 2002, environmental reaction, $\mathrm{pH}(\mathrm{KCl}) \mathrm{pH}$ LVS ISO 10390: 2006, organic matter content LVS EN 13039: 2012, ammonium nitrogen LVS ISO 5664: 2004 L / NAC: 2007, pH level LVS EN 13037: 2012 methods.

Statistical analysis of data was performed with SAS / STAT 9.22 software package. Standard errors of the means (SEM) was calculated. The results of the study was compared using a t-test. Statistical significances was assessed at $(\mathrm{P}<0.05)$. 
Environment. Technology. Resources. Rezekne, Latvia Proceedings of the $13^{\text {th }}$ International Scientific and Practical Conference. Volume 1, 95-100

\section{RESULTS AND DISCUSSION}

The geographical area of production of the soybeans might affect the protein quality and nutrient content of the corresponding soybean meal. However, the feed compound industry has paid little attention to the influence of the country of origin of the beans on the chemical composition, amino acid (AA) profile and protein quality of the SBM [18].

Comparing the chemical composition of average indicators of soybeans grown and extruded in Latvia with the research results of Ibáñeza et al., where was included the data obtained from 18 published papers from 2002 to 2018 with a total of 1944 samples in which the chemical composition and protein quality of soybean meal of different origins were compared [18], we found that Latvian soy cakes had lower protein, starch calcium and phosphorus contents, higher content of crude fiber than those presented by Ibáñeza et al (Table 1).

Data from the meta-analysis suggest that the chemical composition, protein quality and nutritive value of the soybean meal depend on the country of origin of the bean. Consequently, different matrices should be used in feed formulation for commercial SBM obtained from beans of different origins [18].

TABLE 1 SOYBEAN CAKE AND SOYBEAN MEAL CHEMICAL ANALISES

\begin{tabular}{|c|c|c|c|}
\hline \multirow{2}{*}{ Traits } & \multicolumn{3}{|c|}{ Soybean products } \\
\cline { 2 - 4 } & $\begin{array}{c}\text { Full fat } \\
\text { soybean cakes }\end{array}$ & $\begin{array}{c}\text { Soybean } \\
\text { cakes }\end{array}$ & $\begin{array}{c}\text { Soybean } \\
\text { meal* }\end{array}$ \\
\hline Protein, \% & 36.44 & 42.94 & 46.4 \\
\hline Fat, \% & 19.59 & 7.02 & 16.6 \\
\hline Ash, \% & 6.67 & 7.12 & 6.51 \\
\hline Crude fiber, \% & 5.53 & 5.43 & 4.65 \\
\hline Starch, \% & 2.80 & 3.27 & 4.34 \\
\hline Calcium, \% & 0.21 & 0.22 & 0.35 \\
\hline Phosphorus, \% & 0.53 & 0.57 & 0.64 \\
\hline *Ibáñeza et al. 2020. [18] & & \\
\hline
\end{tabular}

The energy and nutrient requirements of the lactating sows depends on her weight, milk yield and composition, and to a lesser extent, the environmental conditions under which she is housed. [19]. Lactation is the most demanding stage of the reproductive cycle, and milk production requires significantly more energy, which has a negative effect on the short- and long-term productivity of sows and affects the growth and development of piglets. Lactating sows should be full-fed during lactation to obtain maximum milk production, minimize weight loss and improve rebreeding performance [20]. During our study, the growth rates of suckling piglets were similar in both groups (Table 2), were not observed significant differences $(\mathrm{P}>0.05)$.

TABLE 2 Piglet GROWTH AND RETENTION RATES (MEAN \pm SEM)

\begin{tabular}{|l|c|c|}
\hline \multirow{2}{*}{ Traits } & \multicolumn{2}{|c|}{ Groups } \\
\cline { 2 - 3 } & Control group & Trial group \\
\hline Birth weight, kg & $1.42 \pm 0.25$ & $1.38 \pm 0.29$ \\
\hline $\begin{array}{l}\text { Live weight in 28 } \\
\text { days, kg }\end{array}$ & $6.99 \pm 0.60$ & $7.07 \pm 1.15$ \\
\hline $\begin{array}{l}\text { Live weight gain per } \\
\text { day, kg }\end{array}$ & $0.198 \pm 0.019$ & $0.203 \pm 0.035$ \\
\hline $\begin{array}{l}\text { Number of live born } \\
\text { piglets per litter }\end{array}$ & $10.70 \pm 1.13$ & $11.00 \pm 1.08$ \\
\hline $\begin{array}{l}\text { Number of piglets per } \\
\text { litter at the age of } 28 \\
\text { days }\end{array}$ & $9.40 \pm 1.77$ & $9.50 \pm 1.42$ \\
\hline $\begin{array}{l}\text { Retention of piglets } \\
\text { at the age of 28 days, } \\
\% .\end{array}$ & 87.5 & 86.4 \\
\hline
\end{tabular}

Between live born piglets per litter, number of piglets per litter at the age of 28 days and retention of piglets at the age of 28 days were no significant differences $(\mathrm{P}>0.05)$.

The relative milk yield of sows was determined based on litter weight at 21 days old (Table 3 ). The milk yield of sows depends on the number of piglets and their individual weight at 21 days old, and is correlated directly with litter weight at birth.

TABLE 3 IMPACT OF MILK YIELDS ON PIGLETS AT 21 DAY (MEAN \pm SEM)

\begin{tabular}{|l|c|c|}
\hline \multirow{2}{*}{ Traits } & \multicolumn{2}{c|}{ Groups } \\
\cline { 2 - 3 } & Control group & Trial group \\
\hline $\begin{array}{l}\text { Number of piglets in a litter at } \\
\text { the age of 21 days. }\end{array}$ & $9.60 \pm 1.45$ & $9.70 \pm 1.41$ \\
\hline $\begin{array}{l}\text { Piglet live weight at 21 days } \\
\text { of age, kg }\end{array}$ & $5.51 \pm 0.59$ & $5.70 \pm 1.12$ \\
\hline $\begin{array}{l}\text { Litter weight of piglets at 21 } \\
\text { days of age, kg }\end{array}$ & $53.60 \pm 10.96$ & $55.7 \pm 13.64$ \\
\hline
\end{tabular}

The careful management of sow feeding during lactation can markedly increase feed intake and facilitate greater milk yields.

This represents an opportunity commercially to maximize the weaning weights of all piglets, including low birth weight piglets. Furthermore, improved sow lactation nutrition can significantly reduce pre weaning mortality of low birth weight animals. This, in turn, will greatly increase the number of animals weaned, improving output and profitability at farm level [21]. Therefore, by weighing all litters at 21 days of age, sows' milk can be monitored. The inclusion of soy cakes grown and processed in Latvia in lactating sow feed increased sows milk yield traits by $3.9 \%$ at 21 day of piglet age. There were no significant differences between groups. That indicated that the sows were fed with similar nutrients, soybean cakes and soybean 
meal were equally absorbed in the digestive tract of both groups of sows. Were provided all the nutrients and produced similar amounts of milk. Local soybean cakes and imported soybean had a similar feeding efficiency to suckling piglets.

Feed effects on fattening pig growth traits and carcasses performance was made in this study. The study lasted 140 days from weaning of piglets at 28 days of age until the end of the fattening period. Live weight rates for pigs in both groups at 28, 66, and 115 days of age were similar (Table 4).

TABLE 4 PIGS LIVE WEIGHTS AND LIVE WEIGHT GAINS (MEAN \pm SEM)

\begin{tabular}{|l|c|c|}
\hline \multirow{2}{*}{ Traits } & \multicolumn{2}{|c|}{ Groups } \\
\cline { 2 - 3 } & Control group & Trial group \\
\hline $\begin{array}{l}\text { Live weight at the age of } \\
\text { 28 days, kg }\end{array}$ & $9.50 \pm 0.14$ & $9.10 \pm 0.15$ \\
\hline $\begin{array}{l}\text { Live weight at the age of } \\
\text { 66 days, kg }\end{array}$ & $27.05 \pm 0.57$ & $27.58 \pm 0.55$ \\
\hline $\begin{array}{l}\text { Live weight at the age of } \\
115 \text { days,kg }\end{array}$ & $64.46 \pm 1.15$ & $64.94 \pm 1.25$ \\
\hline $\begin{array}{l}\text { Live weight at the age of } \\
168 \text { days, kg }\end{array}$ & $100.95 \pm 1.95$ & $104.40 \pm 2.33$ \\
\hline $\begin{array}{l}\text { Live weight gain per day } \\
\text { for the period from } 28 \text { to } \\
66 \text { days of age, kg }\end{array}$ & $0.48 \pm 0.02$ & $0.47 \pm 0.02$ \\
\hline $\begin{array}{l}\text { Live weight gain per day } \\
\text { for the period from } 66 \text { to } \\
115 \text { days of age, kg }\end{array}$ & $0.76 \pm 0.03$ & $0.76 \pm 0.03$ \\
\hline $\begin{array}{l}\text { Live weight gain per day } \\
\text { for the period from 115 } \\
\text { to 168 days of age, kg }\end{array}$ & $0.69 \pm 0.04$ & $0.70 \pm 0.04$ \\
\hline $\begin{array}{l}\text { Live weight gain per day } \\
\text { for the period from } 28 \text { to } \\
\text { 168 days of age, kg }\end{array}$ & $0.66 \pm 0.04$ & $0.68 \pm 0.02$ \\
\hline \begin{tabular}{l} 
Live weight gain, kg \\
\hline
\end{tabular} & $92.28 \pm 2.36$ & $94.92 \pm 2.02$ \\
\hline
\end{tabular}

The final weight of pigs at the trial group was $104.4 \mathrm{~kg}$, which was 3.4\% higher than the control group pigs but it is not significant difference $(\mathrm{P}>0.05)$ between live weights in pigs groups.

Live weight gain per day for the period from 28 to 66 days, 67 to 115 days, and 116 to 168 days were similar between groups and showed no significant differences $(\mathrm{P}>$ 0.05 ) Throughout the fattening period from the age of 28 days until the end of the fattening period at the age of 168 days, was found $3.42 \%$ higher live weight of the pigs in the trial group. No significant differences $(\mathrm{P}>0.05)$ were found between live weight gains in pigs groups.

The feed consumption of fattening pigs, which were fed with soy cakes bred and processed in Latvia, was 3.48\% lower compared to the control group (Table 5). On average, one animal from the trial group consumed 70 grams less feed per day than the control group of pigs.
TABLE 5 FEED CONSUMPTION AND CONVERSION

\begin{tabular}{|l|c|c|}
\hline \multirow{2}{*}{ Traits } & \multicolumn{2}{c|}{ Groups } \\
\cline { 2 - 3 } & $\begin{array}{c}\text { Control } \\
\text { group }\end{array}$ & Trial group \\
\hline Feed consumption per animal, kg & 314.9 & 304.3 \\
\hline Feed consumption per day, kg & 2.24 & 2.17 \\
\hline Feed conversion kg, kg & 3.41 & 3.21 \\
\hline
\end{tabular}

Accordingly, feed conversion, feed consumed per kg of live weight gain in the trial group was by 200 grams or $5.87 \%$ better than in the control group of pigs.

The carcass weight of the trial group pigs was on average $2.57 \mathrm{~kg}$ or $3.3 \%$ higher than the control group pigs (Table 6). The lean meat content and carcases length were similar between the groups. Carcases quality indicators did not show significant differences $(P>0.05)$ between the groups of imported and locally produced soy products.

When evaluating the results of chemical analyzes of muscle tissue, the observed amino acid content was similar, significant differences were not observed between the groups. Content of all determined amino acids was slightly higher in the samples of the trial group. The amount of intramuscular fat in the muscle tissue of the trial group of pigs was $4.15 \%$, which was $2.6 \%$ lower than in the muscle tissue of the control group of pigs. The cholesterol content in the muscle tissue of the experimental group pigs was $16.9 \%$ lower. The $\mathrm{pH}$ of the muscle tissue was similar.

Feeding fattening pigs, with feed were included soybeans cakes grown and processed in Latvia, was observed a tendency to decrease the organic matter content in the trial group by $3.25 \%$, (Table 7 ) as well as lower levels of total phosphorus, ammonium nitrogen (N / NH4) in manure compared to the control group.

TABLE 6 PIGS CARCASES TRAITS AND CHEMICAL COMPOSITION OF MEAT $(\mathrm{MEAN} \pm \mathrm{SEM})$

\begin{tabular}{|l|c|c|}
\hline \multirow{2}{*}{ Traits } & \multicolumn{2}{c|}{ Groups } \\
\cline { 2 - 3 } & $\begin{array}{c}\text { Control } \\
\text { group }\end{array}$ & $\begin{array}{c}\text { Trial } \\
\text { group }\end{array}$ \\
\hline Carcass weight, kg & $74.57 \pm 1.56$ & $\begin{array}{c}77.14 \pm 1.8 \\
5\end{array}$ \\
\hline Lean meat content,\% & $61.30 \pm 0.18$ & $\begin{array}{c}60.82 \pm 0.1 \\
9\end{array}$ \\
\hline Carcass length from the first rib, cm & $80.50 \pm 0.74$ & $\begin{array}{c}80.80 \pm 0.8 \\
5\end{array}$ \\
\hline $\begin{array}{l}\text { Hydroxyproline }<0.05 \text { (LOQ) g } 100 \\
\text { g }^{-1} ;\end{array}$ & $<0.05$ & $<0.05$ \\
\hline Alanine, g $100 \mathrm{~g}^{-1}$ & 1.26 & 1.30 \\
\hline Arginine, g $100 \mathrm{~g}^{-1}$ & 1.38 & 1.43 \\
\hline Aspartic acid, g $100 \mathrm{~g}^{-1}$ & 2.06 & 2.11 \\
\hline Cysteine + Cystine, g $100 \mathrm{~g}^{-1}$ & 0.23 & 0.24 \\
\hline Phenylalanine, g $100 \mathrm{~g} \mathrm{~g}^{-1}$ & 0.94 & 0.95 \\
\hline Glycine, g $100 \mathrm{~g} \mathrm{~g}^{-1}$ & 0.98 & 1.09 \\
\hline
\end{tabular}


Environment. Technology. Resources. Rezekne, Latvia Proceedings of the $13^{\text {th }}$ International Scientific and Practical Conference. Volume 1, 95-100

\begin{tabular}{|c|c|c|}
\hline \multirow[b]{2}{*}{ Traits } & \multicolumn{2}{|c|}{ Groups } \\
\hline & $\begin{array}{c}\text { Control } \\
\text { group }\end{array}$ & $\begin{array}{c}\text { Trial } \\
\text { group }\end{array}$ \\
\hline Glutamic acid, g $100 \mathrm{~g}^{-1}$ & 3.23 & 3.35 \\
\hline Histidine, g $100 \mathrm{~g}^{-1}$ & 0.92 & 0.94 \\
\hline Isoleucine, g $100 \mathrm{~g}^{-1}$ & 0.99 & 1.02 \\
\hline Leucine, g $100 \mathrm{~g}^{-1}$ & 1.80 & 1.85 \\
\hline Lysine, g $100 \mathrm{~g}^{-1}$ & 1.94 & 1.99 \\
\hline Methionine, g $100 \mathrm{~g}^{-1}$ & 0.57 & 0.57 \\
\hline Proline, g $100 \mathrm{~g}^{-1}$ & 0.81 & 0.89 \\
\hline Serine, g $100 \mathrm{~g}^{-1}$ & 0.88 & 0.90 \\
\hline Threonine, g $100 \mathrm{~g}^{-1}$ & 1.01 & 1.02 \\
\hline Valine, g $100 \mathrm{~g}^{-1}$ & 1.06 & 1.07 \\
\hline Cholesterol, mg 100g ${ }^{-1}$ & 81.50 & 67.75 \\
\hline Total fat content,\% & 6.75 & 4.15 \\
\hline Humidity,\% & 71.10 & 72.55 \\
\hline Protein, \% & 21.30 & 21.95 \\
\hline $\mathrm{pH}$ & 5.47 & 5.44 \\
\hline Tryptophan, g $100 \mathrm{~g}^{-1}$ & 0.29 & 0.29 \\
\hline Ornithine $<0.01$ (LOQ) g $100 \mathrm{~g}^{-1}$ & $<0.01$ & $<0.01$ \\
\hline $\begin{array}{l}\text { Hydroxyproline }<0.05 \text { (LOQ) g } 100 \\
\mathrm{~g}^{-1} ;\end{array}$ & $<0.05$ & $<0.05$ \\
\hline
\end{tabular}

Pigs fed soybean cakes grown and processed in Latvia found a 3.48\% lower feed consumption and feed conversion was $5.87 \%$ better. The carcass weight of the trial group was on average 3.3\% higher. Carcass quality indicators did not show significant differences between groups. The amino acid content of muscle tissue was similar. The muscle cholesterol content of the pigs of the trial group was $16.9 \%$ lower. Feeding local soybean cakes to fattening pigs reduce environmental pollution by organic matter, total phosphorus and ammonium nitrogen.

Using soy cakes grown and processed in Latvia, it was possible to develop feed rations for lactating sows and fattening pigs, which showed similar results for the use of imported soybean

\section{ACKNOWLEDGEMENTS}

Publication and dissemination of research results were carried out due to the support for EIP groups cooperation project 'New technologies and economically viable solutions for the production of local feed for pig production: cultivation of non-genetically modified soybeans and new barley varieties in Latvia’ No. 18-00A01612-000015.

\section{REFERENCES}

[1] Navicha, W.B., Y. Hua, K. Masamba and C. Zhang. ” Effect of roasting temperatures and times on test parameters used in determination of adequacy of soybean processing“. Adv. J. Food Sci. Technol. 13, 2017, pp. 22-28. [Online]. Available: https://www.researchgate.net/publication/318254957_Optimizatio $\underline{\mathrm{n} \text { of soybean roasting parameters in developing_nutritious_an }}$ d_lipoxygenase_free_soymilk [Accessed March 16, 2021]

[2] P. Florou-Paneri, E. Christaki, I. Giannenas, E. Bonos, I. Skoufos, A. Tsinas, A. Tzora and J. Peng. "Alternative protein sources to soybean meal in pig diets”. Journal of Food, Agriculture \& Environment . Vol.12 (2): 2014, pp. 655-660. [Online]. Available: https://www.cabdirect.org/cabdirect/abstract/20143310441. [Accessed March 18, 2021].

[3] H. H. Stein, J. A. Roth, K. M. Sotak and O. J. Rojas. "Nutritional Value of Soy Products Fed to Pigs". University of Illinois, UrbanaChampaign 'Swine Focus'. 01 August 2013

[Online].

Available.

https://www.thepigsite.com/articles/nutritional-value-of-soyproducts-fed-to-pigs [Accessed March 16, 2021].

[4] N. Javed, M. T. Javed, M. A. Mirza, G. Saleem, B. Aslam, F. Manzoor, A. Rehman, M. Aslam, M. N. Bhutta, S. Faizan "Pathological effect of replacement of solvent extracted soybean meal with expeller extracted soybean meal in broilers”. Chemistry Pakistan Journal of Agricultural Sciences. V. 57(4); 2020, pp. 969973.

[5] G. S. Gilani, K. A. Cockell, E. Sepehr. "Effects of antinutritional factors on protein digestibility and amino acid availability in foods”. J. AOAC Int.; 88.1989, pp.967-987. [Online]. Available: https://pubmed.ncbi.nlm.nih.gov/16001874/ [Accessed March 16, 2021].

[6] G. Grant. "Antinutritional effects of soybean a review". Prog. Food Nutr. Sci. (Oxford) 1989; 13(3-4) :317-348. [Online]. Available: https://pubmed.ncbi.nlm.nih.gov/2699045/

[Accessed March 17, 2021].

[7] M. Ramos. Why Extrude Soybeans. November 3, 2016. [Online]. Available:

https://www.instapro.com/en/blog/nutritionandtechnologies/why-extrude-soybeans/ [Accessed Mart 10, 2021].

[8] R. Yasothai. “ Antinutritional factors in soybean meal and its deactivation”. International Journal of Scie nce, Environment and 
Technology. ISSN 2278-3687 (O), Vol. 5, No 6, 2016, pp. 3793 $-3797$.

[9] Y. Liu, O. J. Rojas, and H. H. Stein. "Effects of extrusion of corn and oats on the digestibility of energy and nutrients in diets fed to pigs”. J. Anim. Sci. 93(Suppl. 2): 2015, pp.134-135. [Online]. Available: https://nutrition.ansci.illinois.edu/node/1014 [Accessed March 15, 2021].

[10] O. J. Rojas, E. Vinyeta and H H Stein. "Effects of pelleting, extrusion, or extrusion and pelleting on energy and nutrient digestibility in diets containing different levels of fiber and fed to growing pigs”. J. Anim. Sci. 94: 2016, pp.1951-1960. [Online] Available: Oxford Academic Online

ttps://academic.oup.com/jas/article-abstract/94/5/1951/4701614 [Accessed March 18, 2021].

http;//doi:10.2527/jas.2015-0137.

[11] D. A. Rodriguez, S. A. Lee, M. R. C. de Godoy, H. H. Stein "Extrusion of soybean hulls does not increase digestibility of amino acids or concentrations of digestible and metabolizable energy when fed to growing pigs”. Translational Animal Science, Volume 4, Issue 3, July 2020, txaa169.

[Online]. Available: Oxford Academic Online, https://academic.oup.com/tas/article/4/3/txaa169/5903553. [Accessed March 18, 2021]. https://doi.org/10.1093/tas/txaa169

[12] D. Miladinovic. Optimising the extrusion process. 20-05-2019. [Online]. Available: https://www.allaboutfeed.net/author/dejanmiladinovic/

[Accessed March 18, 2021].

[13] Pig welfare requirements Regulations of the Cabinet of Ministers No. 743. [Online]. Available: https://likumi.lv/ta/id/194745-cukulabturibas-prasibas [Accessed March 16, 2021].

[14] L. Degola, V. Sterna, I. Jansons, S. Zute. "The nutrition value of soybeans grown in Latvia for pig feeding”. Agronomy Research 17(5), 2019, pp. 1874-1880. [Online].Available: http://dspace.emu.ee/xmlui/handle/10492/5099 [Accessed March $18,2021]$

https://doi.org/10.15159/AR.19.158

[15] B. Grisdale, , L. L. Christian.; H. R Cross; D. J. Meisinger, M. F. Rothschild and R. G. Kauffman. "Revised Approaches to
Estimate Lean of Pork Carcasses of Known Age or Days on Test". Animal Science Publications. 1984, pp. 312.

[16] Rules for the classification of animal carcase. Regulations of the Cabinet of Ministers No. 416. [Online]. Available https:/likumi.lv/ta/id/300432-dzivnieku-liemenu-klasifikacijasnoteikumi [Accessed March 16, 2021].

[17] I. Jansons, L. Degola, V. Sterna and S. Zute. "Influence of local extruded soybean cake and imported soybean meal on fattening pig productivity and pork quality”. Agronomy Research, 18 (Special Issue 2) 2020, pp. 1307-1315. [Online]. Available: https://dspace.emu.ee/xmlui/handle/10492/5700 [Accessed March 16, 2021]. https://doi.org/10.15159/AR.20.102

[18] M. A. Ibáñeza, C. de Blasb, L. Cámarab, G. G. Mateosb. "Chemical composition, protein quality and nutritive value of commercial soybean meals produced from beans from different countries: A meta-analytical study”. Animal Feed Science and Technology. Volume 267, September 2020, 114531. [Online]. Available:

https://www.sciencedirect.com/science/article/pii/S037784012030 4351 [Accessed March 16, 2021]. https://doi.org/10.1016/j.anifeedsci.2020.114531

[19] F. Aherne. Feeding the lactating sow. Pork Information Gateway Factsheet PIG 07-01-05. 2005. [Online]. Available: https://porkgateway.org/resource/feeding-the-lactating-sow-2/ [Accessed March 15, 2021].

[20] , D. E. Reese, R. C. Thaler, M. C. Brumm, A. J. Lewis, P. S. Miller, and G. W. Libal. "Swine Nutrition Guide". Faculty Papers and Publications in Animal Science . 69. 2000. [Online]. Available: https://digitalcommons.unl.edu/animalscifacpub/694 [Accessed March 16, 2021].

[21] S. J. Hawe, N. Scollan, A. Gordon, E. Magowan. "Impact of sow lactation feed intake on the growth and suckling behavior of low and average birthweight pigs to 10 weeks of age” Translational Animal Science, Volume 4, Issue 2, April 2020, pp. 655-665. [Online]. Available: Oxford Academic Online, https://academic.oup.com/tas/article/4/2/655/5835298 [Accessed March 12, 2021]. https://doi.org/10.1093/tas/txaa057 